\title{
Leaders, Legends and Felons: Negotiating portraiture, from veneration to vandalism
}

\section{Angela Carr}

Volume 30, numéro 1-2, 2005

The Portrait Issue

La question du portrait

URI : https://id.erudit.org/iderudit/1069666ar

DOI : https://doi.org/10.7202/1069666ar

\section{Aller au sommaire du numéro}

\section{Éditeur(s)}

UAAC-AAUC (University Art Association of Canada | Association d'art des universités du Canada)

\section{ISSN}

0315-9906 (imprimé)

1918-4778 (numérique)

\section{Découvrir la revue}

\section{Citer cet article}

Carr, A. (2005). Leaders, Legends and Felons: Negotiating portraiture, from veneration to vandalism. RACAR : Revue d'art canadienne / Canadian Art Review, 30(1-2), 101-113. https://doi.org/10.7202/1069666ar

\section{Résumé de l'article}

En 2003, lors de l'arrivée en Iraq de la coalition dirigée par les États-Unis, un grand nombre de portraits de Saddam Hussein, dirigeant de l'Iraq à l'époque, furent détruits. Deux ans auparavant, les talibans avaient dynamité deux bouddhas géants, sculptés dans les falaises du nord de l'Afghanistan. Même si la destruction violente d'images est traditionnellement qualifiée de vandalisme ou d'iconoclasme, le « texte " esthétique, selon Umberto Eco, serait davantage un outil de communication que de représentation, outil dont les significations peuvent changer et auquel on ne réservera pas le même accueil avec le temps. D’après le concept de communauté imaginée de Benedict Anderson, les monuments d'État illustrent des idéaux collectifs, tandis que Michael Taussig estime que l'État est un " autre » fétichisé, distinct de la population qu'il est censé servir. Dans les cas où les portraits d'État favorisent un culte de la personnalité, ces images rappellent constamment le pouvoir du régime en place et définissent le territoire où ce pouvoir s'exerce. Contrairement à ce que soutient Antonio Gramsci au sujet du concept d'hégémonie, les portraits de dictateurs ne consolident pas l'ascendant sur les classes : ils orchestrent un culte à l'égard d'une personne.

La transgression des règles relatives au sujet ou à la présentation peut entraîner des réactions violentes. Dans ces cas, entre autres, le spectateur peut considérer l'image comme un moyen de communiquer avec l'artiste, la personne représentée ou le public en général. Des « communications » de ce type, notamment par la violence, résistent aux stratégies analytiques liées au signifiant flottant, au simulacre et au fétiche, même si ces démarches restent utiles en ce qui concerne d'autres aspects de l'analyse du portrait.
Tous droits réservés (C) UAAC-AAUC (University Art Association of Canada | Association d'art des universités du Canada), 2006
Ce document est protégé par la loi sur le droit d'auteur. L'utilisation des services d'Érudit (y compris la reproduction) est assujettie à sa politique d'utilisation que vous pouvez consulter en ligne.

https://apropos.erudit.org/fr/usagers/politique-dutilisation/ 


\title{
Leaders, Legends and Felons: negotiating portraiture, from veneration to vandalism
}

\author{
Angela Carr, Carleton UnIVERSITY
}

\section{Résumé}

En 2003, lors de l'arrivée en Iraq de la coalition dirigée par les ÉtatsUnis, un grand nombre de portraits de Saddam Hussein, dirigeant de l'Iraq à l'époque, furent détruits. Deux ans auparavant, les talibans avaient dynamité deux bouddhas géants, sculptés dans les falaises du nord de l'Afghanistan. Même si la destruction violente d'images est traditionnellement qualifiée de vandalisme ou d'iconoclasme, le « texte » esthétique, selon Umberto Eco, serait davantage un outil de communication que de représentation, outil dont les significations peuvent changer et auquel on ne réservera pas le même accueil avec le temps.

D'après le concept de communauté imaginée de Benedict Anderson, les monuments d'État illustrent des idéaux collectifs, tandis que Michael Taussig estime que l'État est un « autre » fétichisé, distinct de la population qu'il est censé servir. Dans les cas où les portraits d'État favorisent un culte de la personnalité, ces images rappellent constamment le pouvoir du régime en place et définissent le territoire où ce pouvoir s'exerce. Contrairement à ce que soutient Antonio Gramsci au sujet du concept d'hégémonie, les portraits de dictateurs ne consolident pas l'ascendant sur les classes : ils orchestrent un culte à l'égard d'une personne.

La transgression des règles relatives au sujet ou à la présentation peut entrainer des réactions violentes. Dans ces cas, entre autres, le spectateur peut considérer l'image comme un moyen de communiquer avec l'artiste, la personne représentée ou le public en général. Des «communications » de ce type, notamment par la violence, résistent aux stratégies analytiques liées au signifiant flottant, au simulacre et au fétiche, même si ces démarches restent utiles en ce qui concerne d'autres aspects de l'analyse du portrait.
A likeness is a gift and remains unmistakable - even when hidden behind a mask.

A likeness can be effaced. Today Che Guevara sells Tshirts, that's all that is left of his likeness.

Are you sure?

John Berger, "Will It Be a Likeness?" The Shape of a Pocket (2002), 258.

$\mathrm{D}$ uring the entry of the American-led coalition into Iraq in 2003, tens of thousands of sculptural, mosaic, and painted portraits of then Iraqi leader Saddam Hussein were destroyed (fig. 1).' Two years earlier a pair of ancient, monumental Buddhas carved into the sandstone cliffs of Bamiyan, Afghanistan, had been dynamited by the Taliban to enforce Islamic interdictions against graven images (fig. 2,3). ${ }^{2}$ Each set of events in very different ways demonstrates the significance with which seemingly inert objects may become invested, the variety of meanings they absorb, and how such meanings change over time.

Usually, the violent destruction of images is classed in two typologically different ways. University of Amsterdam art historian Dario Gamboni has described vandalism as an activity carried out by individuals, acting alone or in groups, on a seemingly random basis. ${ }^{3}$ Iconoclasm, on the other hand, is a collective phenomenon linked to a conscious program of selective destruction. One term is commonly applied to secular contexts, the other to destructions actuated by cultural or religious prohibitions related to imagery. ${ }^{4}$ This type of classification focuses upon the singular event of violent destruction.
In this paper I want to probe some of the strategies used to "read" images, specifically portraits, in relation to their shifting reception over time. Are portraits fetishized objects, or do they, in Lacan's terms, encode "a symbolic order separated only by a fragile border from the materiality of the Real"? F Furthermore, can changing responses to images, from veneration to vandalism, for example, be understood as performative in line with semiotician Umberto Eco's dictum that the "aesthetic text [is] a communicational text"?

The comprehension of an aesthetic text is based on a dialectic between acceptance and repudiation of the sender's codes - on the one hand - and introduction and rejection of personal codes on the other... Thus the semiotic definition of an aesthetic text gives the structured model for an unstructured process of communicative interplay. ${ }^{6}$

Can this interplay and clash of codes, described by Eco, perhaps explain the shifting significance attached to figural images, in the case of changing power dynamics??

In 1991 Richard Brilliant wrote that the referentiality to a "human original" was what distinguished the genre of portraiture from other types of art, a quality he likened to Hans-Georg Gadamer's concept of "occasionality." In contrast, Shearer West, writing in 2004, described portraiture as a form of representation, invested with the processes of commissioning and production. Somewhere in the chasm between referentiality and representation, one must also be able to theorize images as repositories for perpetually negotiable layers of meaning, and at times as unintended vessels for inflammatory new texts. ${ }^{8}$

How does state portraiture traverse the shift from public 
Figure I. "A U.S. soldier watches as a statue of Iraq's President Saddam Hussein falls in central Baghdad's Firdaus Square on 9 April 2003," Ottawa Citizen, 20 March 2004, B5 (Photo: Reuters/Goran Tomasevic, copyright Reuters/Corbis UT0139165).

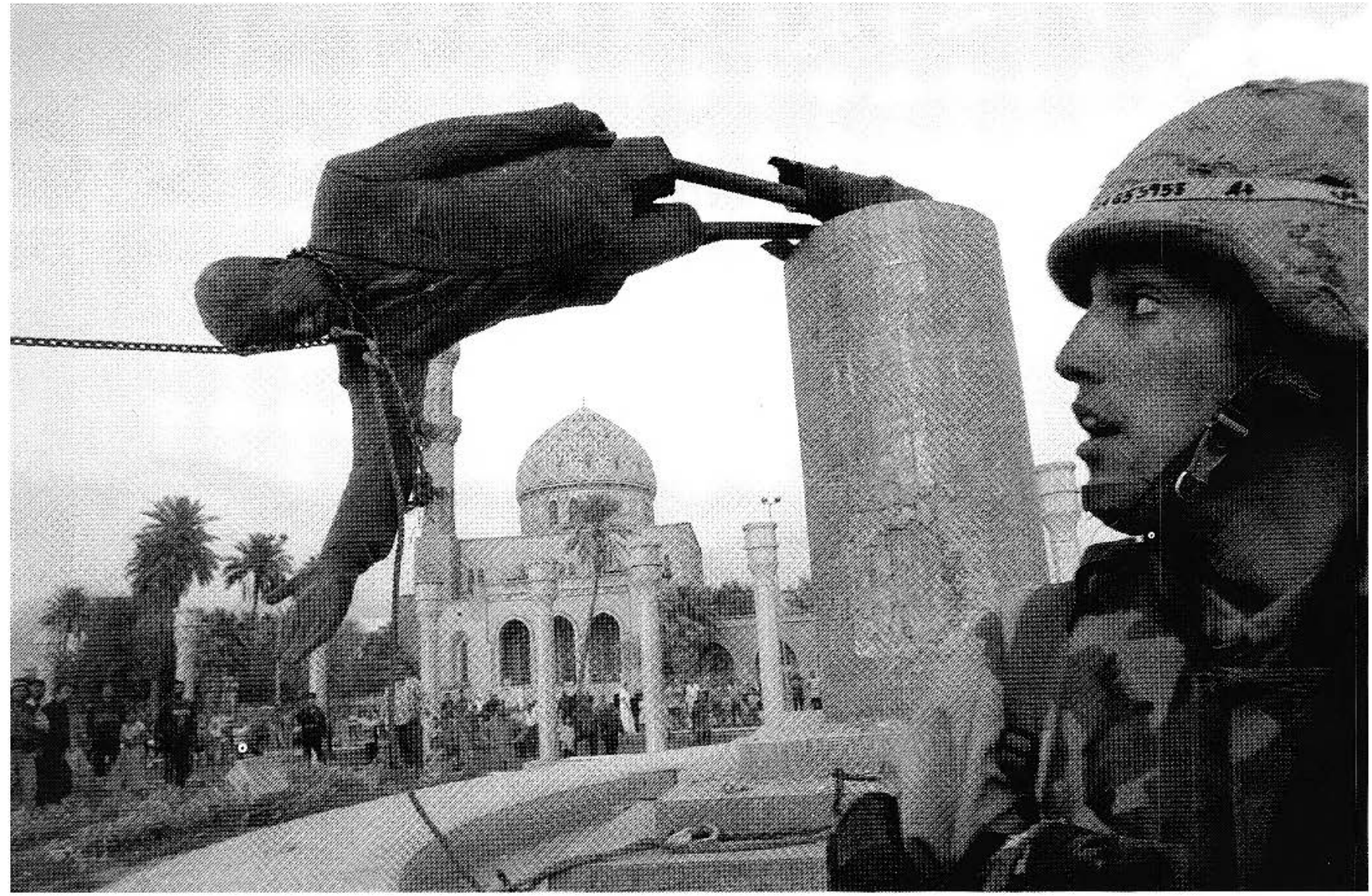

icon to historical flotsam, for example? When dedicated, the portraits of Saddam Hussein sustained a cult of personality, and the ubiquity of the images asserted the power of the regime at every turn, staking out the parameters over which Saddam's regime exercised control. Undisturbed before coalition forces entered Iraq, these images became targets for destruction as the advance proceeded. Just as flags are routinely torn down, burned, or trodden under foot to signal political change, state portraits were destroyed. ${ }^{9}$ This, it might be argued, erased rallying points for supporters of the old regime, and asserted a new political trajectory. Yet, attacks upon figural images appear more directed than those upon other state symbols, perhaps constituting what Syracuse University sociologist Arnold Goldstein has termed "vindictive" or "wanton" vandalism. ${ }^{10}$ All portraits are partly portrayal, and partly portrayed. ${ }^{11}$ The violence addressed to such images is often enfolded within a cathartic ritual that appears to reach beyond the image to address the individual so portrayed.

Most heavily publicized of the many defacements in Iraq was the felling of the monumental statue of Saddam Hussein in Baghdad's Firdaus Square on 9 April 2003. ${ }^{12}$ This came to the attention of Westcrn media because the event took place across the street from the international press headquarters in the Palestine Hotel. First, the figure's head was swathed in the Stars and Stripes, like a condemned man awaiting execution. When Iraqi spectators appeared unreceptive, the American flag was replaced by an Iraqi one, lest "liberation" be read as "conquest." This densely laden exchange was filmed through zoom lenses, which some observers claim transformed a modest cluster of spectators into an assembly of greater magnitude. The highlight of the event was the arrival of an American tank with a cable strong enough to pull the sculpture up by its bolts. During the year that followed, this television footage was ranked as one of the defining moments of the conflict, an assessment long since eclipsed by the daily reports of truly devastating human tragedies. ${ }^{13}$ Some have questioned whether the events of April 2003 should be categorized as "top-down," sparked by the presence of the coalition, or as a grass-roots Iraqi uprising. In the former instance the destruction might be construed as an aspect of battlefield behaviour or as "equity-control" vandalism, whereas the latter would constitute a more visceral or "vindictive" backlash on the part of an oppressed populace. ${ }^{14}$ 
Figure 2. "55-meter-high Buddha statue in Bamiyan town in central Afghanistan is shown on 22 December 1997, before its destruction" (Photo: Reuters/Muzammil Pasha, copyright Reuters/Corbis UTO100299).

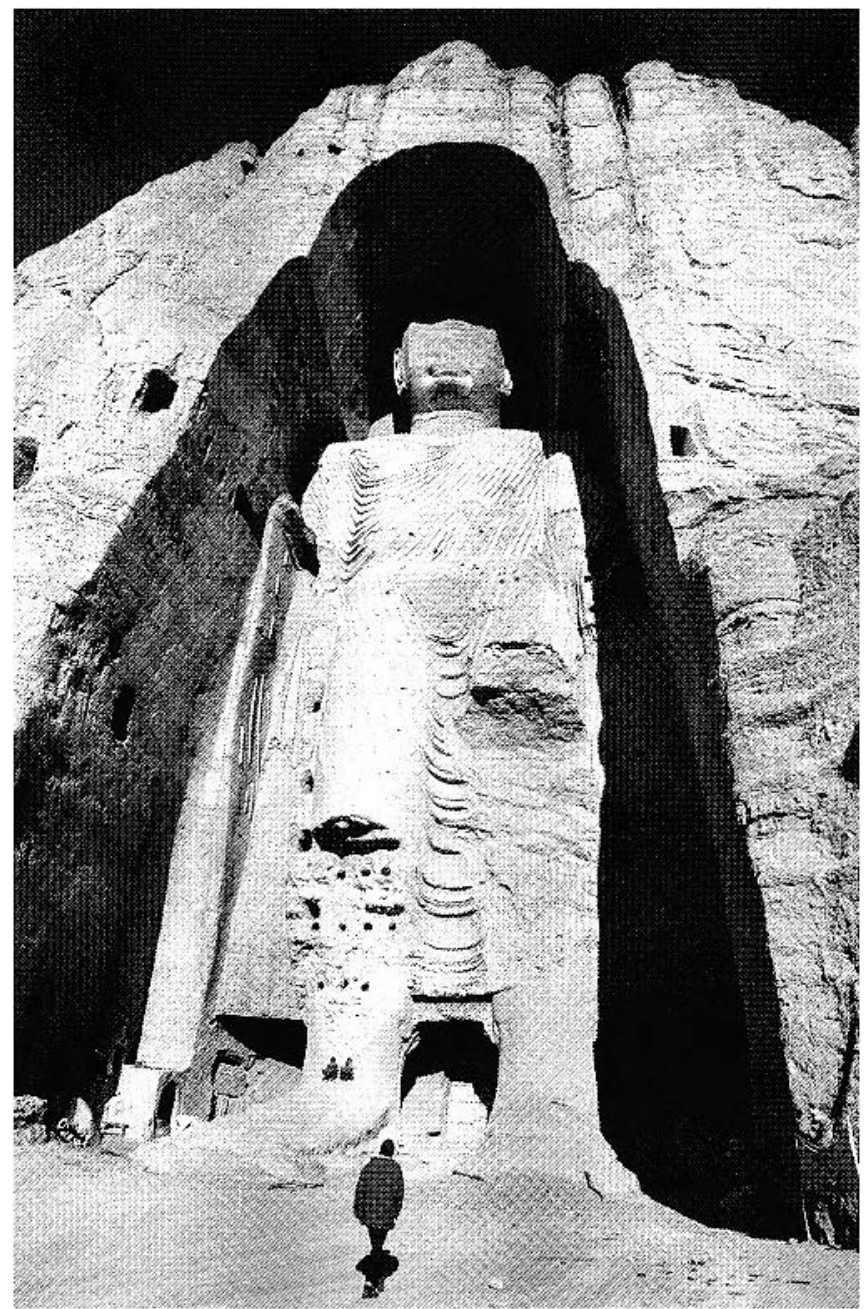

The incident in Baghdad was of course not the only one of its type. Thousands of presidential portraits on public display throughout the country were defaced. As to responses from people "in the street," one television report on the scrapping of a mammoth bronze of the former Iraqi president featured a small boy, running behind the tow truck, vigorously beating the sculptural remnant with his slipper. This was explained to puzzled Western viewers as an insult of the deepest possible magnitude in the vernacular of the Arab world. Such expressions of disdain were legion, but to whom were they addressed? Was this a rebuke to the former Iraqi leader, hiding from those whom he had once oppressed? Was it a rallying cry for freedom? Or was it a response inspired by the presence of the coalition and the international media? ${ }^{15}$ In the first instance, one might argue, per Brilliant, that the assault upon the sculptural fragment "passed" from the object to the "human original," whereas in the latter two instances, communication extended to other audiences,
Figure 3. "Taliban fighter sits on rubble in front of demolished Buddha in Bamiyan" (Photo: Reuters/Sayed Salahuddin, copyright Reuters/Corbis UT0071263).

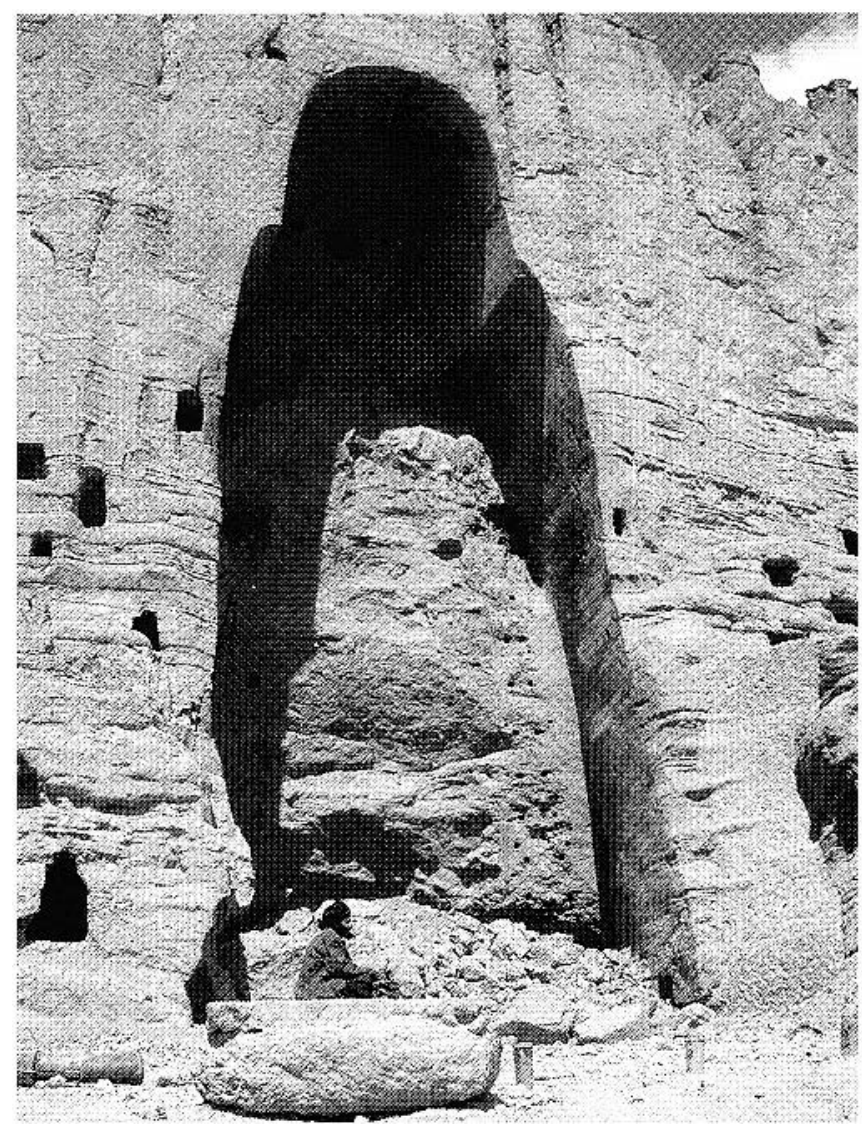

either Iraqi or international, who witnessed the cathartic rituals of execurion in effigy.

Not only do actions, actors, and audiences inform the discourse of state portraiture, but the survival of such works in changing contexts offers fertile ground for study. For example, the detritus of the past Iraqi regime is one thing in the hands of the Iraqi people, but quite another when salvaged by coalition forces. A 135-kilogram sculptural head of Saddam Hussein was deposited in the museum of the Gordon Highlanders in Aberdeen, Scotland, sparking accusations that the museum had countenanced looting. The work had been pulled down as troops entered Basra, and in the chaos that followed it was assumed that Iraqi authorities would not wish to claim the artifact. The regiment reportedly reacted to the uproar by saying that they had "got the head first." 16 Once a symbol of Saddam's power, the image could be regarded as a trophy, a rescued museum piece, or a very large pawn on the chessboard of international politics.

The concept of shifting frames of reference is perhaps best demonstrated in the dramatic rewritings of public portraiture in the former Soviet Union. ${ }^{17}$ Dario Gamboni estimates that in 
1994 there were some 70,000 Lenin monuments in Russia. Their survival he viewed as an index of their continuing historical legitimation. Some works were recontextualized in terms of "heritage." However, there were enough unauthorized removals in Russia that Mikhail Gorbachev saw fit, in 1990, to prohibit defacement of monuments linked to the history of the state. Despite this, Russia officially authorized the removal of the statue of Felix Dzerzhinsky, former head of the Soviet secret police, from outside KGB headquarters in Moscow. ${ }^{18}$ Recently the prospect of re-erecting this statue has been considered, as has the rehabilitation of Stalinist sculptures, now seen as symbols of strength in an era of uncertainty. ${ }^{19}$ These changes in attitude must surely indicate shifting memories of the leader so represented and new contexts arising from the transient historical moment. The works are so deeply imbricated with political, cultural, and social significance, including the state power implicit in their creation, that it appears essential to study the trajectory of their reception over time.

Lenin's tomb is located in central Moscow to memorialize the patriarch of the state. It survived the collapse of Communism, complete with Lenin's embalmed body, openly displayed like a religious relic in a glass case. The site made a successful transition from secular shrine to tourist attraction, until the Yeltsin years, when the prospect of "decent burial" was mooted, unsuccessfully as it turned out. This routine dignity, in Lenin's case, would have implied a loss of status, his public mausoleum being a quasi-sacral recognition of his apotheosis as the father of the Communist experiment.

A generation after Lenin, Josef Stalin borrowed upon the prestige of his predecessor, decreeing that his remains should be installed alongside those of Lenin. Unlike that of Lenin, however, Stalin's claim upon public indulgence was short-lived. His body was removed from public display in 1961 and reinterred near the Kemlin wall, by order of Nikita Khrushchev. ${ }^{20}$ This event was linked to changes in Soviet politics and coincided with moves to denounce Stalin, whose regime had been responsible for the deaths of tens of millions. Elsewhere, public sculptures of Stalin suffered a variety of reinscriptions, according to the actions undertaken by his regime in the locations where the images were erected. In some cases sculptures of Stalin were rewritten into new historical contexts, as reminders of past repression, but in other instances they were simply torn down. ${ }^{21}$

The most unorthodox of the post-Soviet responses was in Lithuania, where the populace began destroying relics of the Soviet era as early as 1989. More recently, however, public sculptures have been restored or replaced, and then collected in the Grutas Forest, near the resort town of Druskininkai. There, sixty-five bronze and granite statues occupy a private precinct of some thirty hectares. Nicknamed by the locals "Stalin World," the site passes for a hybrid between an amusement park and an open-air museum (fig. 4). It is set up to resemble a Soviet prison camp, complete with guard towers and barbed wire. For the comfort and interest of visitors, a cafe, playground, and small zoo are also included. Opened to the public on April Fools Day, the grounds were guarded by a gatekeeper dressed as Stalin, while a Lenin-look-alike fished in one of the ponds. Many took the mockery in good part, but those who had suffered at the hands of Stalin's regime were deeply offended by this attempt to recontextualize the past. For some the memory of grievous wrongs was simply intensified by such an attempt at wry humour. ${ }^{22}$

This re-erection in an entirely new location of public sculpture destined for the graveyard of history also occurred with the bronze equestrian Durbar statue of Edward VII, relocated to Queen's Park, Toronto, in 1969. Designed originally by British sculptor Thomas Brock for Edward Park, in Delhi, India, and unveiled in 1919, the monument came to be seen as a provocative throwback to the days of the British Raj, following independence in 1947. By the 1960s the time was right for relocation. Torontonians took up a public subscription to purchase the work, and lawyer and philanthropist Henry R. Jackman funded the shipping costs. The transfer took place with the approval of the government of India, assisted by the former Canadian High Commissioner and by Governor General Roland Michener. ${ }^{23}$ In Canada, where postcolonial issues were yet to ignite public controversy, the sculpture carried little ideological baggage. In fact, it was such a benign addition to the decorative program of Queen's Park, it may have passed for the kind of public art that some have described as fading into the urban setting. ${ }^{24}$ In his 1997 book, The Destruction of Art, Dario Gamboni quoted one scholar to the effect that public monuments are "a species of art without spectators." ${ }^{25}$ Such ambivalence might be possible in a democratic society, where public art commemorates historic figures or events. But where such images serve the agendas of dictatorial power, it is difficult to rationalize this description. Public art can only fade into the wallpaper when it does not constitute an aggressive reminder of state authority. ${ }^{26}$

Benedict Anderson's view of the nation as an "imagined community" predicated upon shared values implicitly locates public monuments in the realm of communal ideals, but Michael Taussig has argued that the state constitutes a fetishized "other" around which the concept of nation is constructed, while at the same time standing apart from the people it purports to serve. Cults of personality constitute a single individual as the symbol of the state, leaving no other avenue for allegiance. Likeness, pose, authoritative demeanour, and grand scale, conventionalized in the portraits of Saddam Hussein, facilitated instantaneous recognition and furthered the reach of his personal power. This type of portraiture is designed to command reverence, respect, and remembrance, but also to sustain the hegemony of the leader. Intimidating on the one hand, paternalistic on the 
Figure 4. "Josef Stalin sculpture, Grutas Parkas (Stalin World), Lithuania," City Paper News (Baltimore), 3 May 2003, n.p., http://www.citypaper.com/news/story.asp?.id=3258 (accessed 13 October 2005).

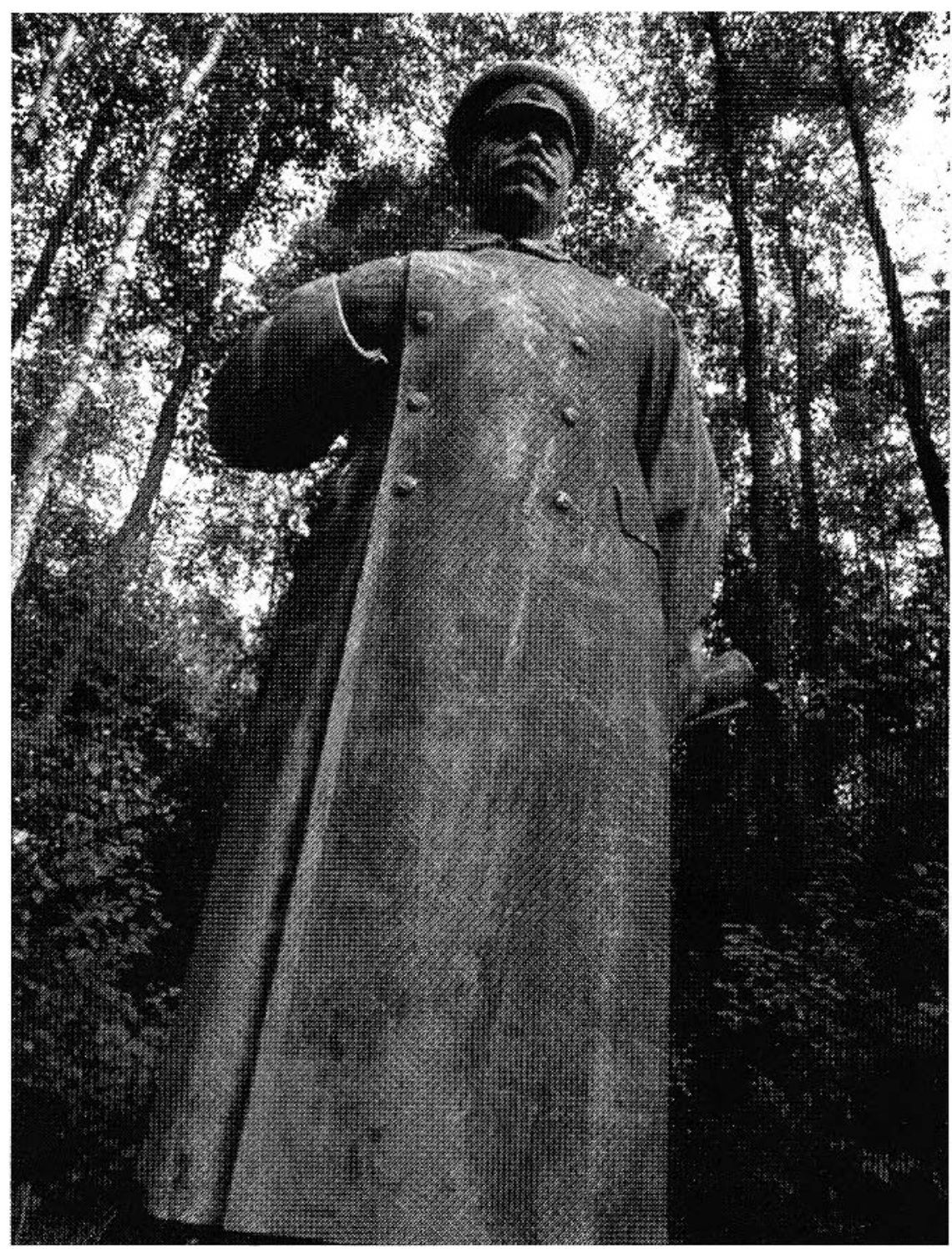

tively "[demarcated] post-colonial political fragments ... unrecognized in international law." 29 Furthermore, the iconography adopted by each side was singular, because the histories and purposes were different for each group. ${ }^{30}$ Hence, popular images, even graffiti, communicate claims of power to an audience literate in its implications.

State portraits combine particular types of convention (the langue, if you will), with representations of likeness (parole), both of which Eco would consider to be culturally and mutually encoded. The conventional aspects of the state portrait and its mass reproduction as an easily recognizable symbol offer a common focal point upon which public loyalty may fix, but with varied results according to culturally based determinants of its reception. In decades past, Canadian classrooms were decorated with a single monarchical portrait of modest dimensions, usually a photograph, in composition and pose similar to the stately and dignified painting of the Queen by Pietro Annigoni. More recently, however, a commission for the Queen's private collection has demonstrated how deeply public expectations of all royal portraits are invested with the conventions attached to state portraiture. When those conventions were prized apart by the worldweary expressionism of Lucian Freud, the press was quick to take an interest. ${ }^{31}$ The transgressive character of Freud's portrait of the Queen was reported as a curiosity, but accepted because the Queen herself had authorized the commission. Yet, there was something distinctly unorthodox about any

other, the genre is not merely what Marxist philosopher Antonio Gramsci conceived as an "ideological structure [asserted by] a dominant class [and] aimed at maintaining, defending or developing [its own] theoretical or ideological 'front." 27 The Saddam portraits were all of this and more: "an ideological front" dcvised solely to perpetuate the power of one individual.

It must not be assumed that spheres of influence are asserted only by state portraiture, however. Popular imagery functions in a similar way. In Belfast, for example, the painting of murals identified urban neighbourhoods for loyalist or nationalist causes, in what some have described as an attempt by "nonstate actors ... to control public space." 28 Such murals, in the words of Michael Dartncll, of the University of Windsor, effec- royal portrait, either public or private, that emphasized every line and care-worn furrow, as if, in the case of public figures, likeness and convention should be one.

More transgressive than Freud's work was Stuart Pearson Wright's portrait of Prince Philip, entitled Homo Sapiens, Lepidum sativum and Calliphora vomitoria, which deliberately subverted formal portraiture to explore a professed "desire [on the part of the artist] to strip portrait painting of its historical function as a propaganda tool for the wealthy and the powerful" (fig. 5). ${ }^{32}$ Commissioned by a philanthropic society to honour Prince Philip's service as patron, the cmbedded critique appalled both the sitter and the commissioners. The work was provocative, precisely because the artist took it upon himself to parody the 
Figure 5. "Stuart Pearson Wright's portrait of Prince Philip, titled Homo sapiens, Lepidum sativum and Calliphora vomitoria," The Daily Telegraph, 30 April 2004, 3 (Photo: Reuters/Kimberly White, copyright Reuters/Corbis 42-15914720).

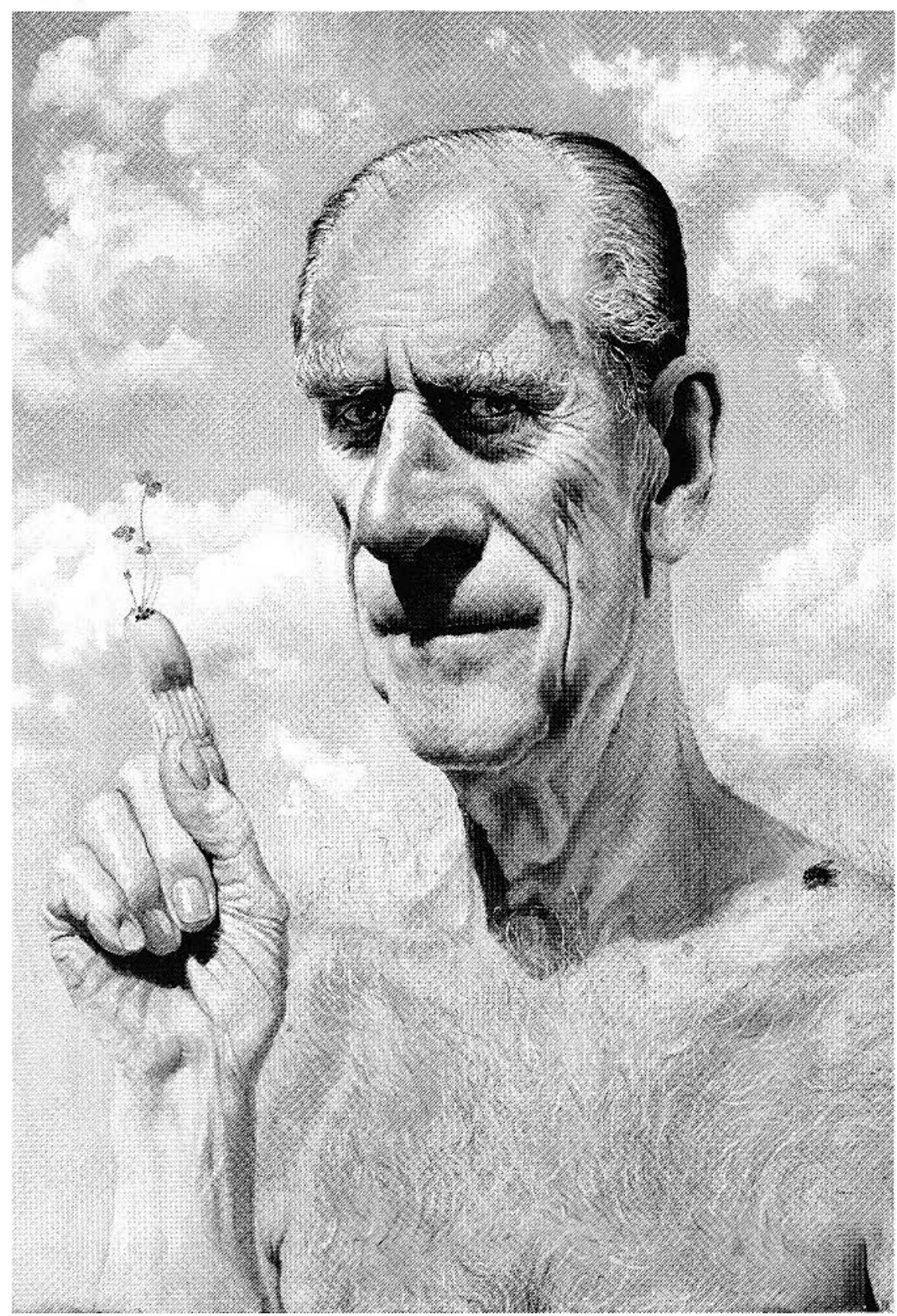

fundamental aspect of artistic creativity. In 1997, for example, Charles Saatchi sent a selection of works from his own collection of contemporary British artists for exhibition in London and New York. The now notorious Sensation show appeared first at the Royal Academy and caused exactly that. Among its most notorious inclusions, at least as far as British audiences were concerned, was the portrait of Myra Hindley by Marcus Harvey. The press billed Myra as the "face of evil," and some visitors pelted the image with ink and eggs. The work was a monumental reproduction of a thirty-year-old newspaper photograph published at the time of Hindley's arrest, three decades earlier, for her collaborations with Ian Brady, the notorious Moors murderer, in the brutal torture and murder of five young children. The artist chose to underline the grossest elements of her crimes by using the cast of a child's handprint to dot his $13^{\prime} \times 10^{\prime}$ reproduction. At the time, Hindley was seeking release from prison, but after the furor remained behind bars, where she died five years later. Her remains had to be cremated separately from those of other prisoners because inmates' families feared their loved ones' ashes might be "contaminated" by hers. ${ }^{34}$ This final expression of revulsion was no less symbolic than the vandalism of Harvey's portrait, nor was it intended to be. Those who remembered what Hindley had done were quite prepared to censure her in death, in effigy, or in any other fashion it might be possible to devise. In effect Harvey had used Hindley's portrait not so much as a representation, but as what Eco describes as a communication: a provocation that generated precisely the negative response he had anticipated. Predictably, perhaps, the public

conventions within which his patrons assumed him to be operating. Wright's work survived, whereas Graham Sutherland's 1954 portrait of Winston Churchill, which so offended the sitter by revealing the infirmities of age, was burned under the personal supervision of his wife, Clementine, following her husband's death. ${ }^{33}$

In contrast to the conventions and expectations of public figures, private collectors often risk audience provocation, and may indeed regard the practice of "pushing the limits" as a revulsion attending the display of Hindley's portrait in Britain, where her crimes had occurred, did not travel with the work to its next stop in Brooklyn, New York. Instead, Chris Ofili's The Holy Virgin Mary appalled visitors, including then New York mayor Rudolf Giuliani. Ofili's work was vandalized with paint to protest its construction from elephant dung and pornographic images. ${ }^{35}$

On occasion audiences may respond negatively whether or not the work is intentionally provocative. In 2003 , for example, 
Figure 6. "RHA stands its ground as Mick O'Dea does a mini-Sensation," (Portrait of Brian [Meehan], Portlaoise, 2003). Circa (Dublin), http://www.recirca.com/artnews/l62.shtml (accessed 19 April 2005).

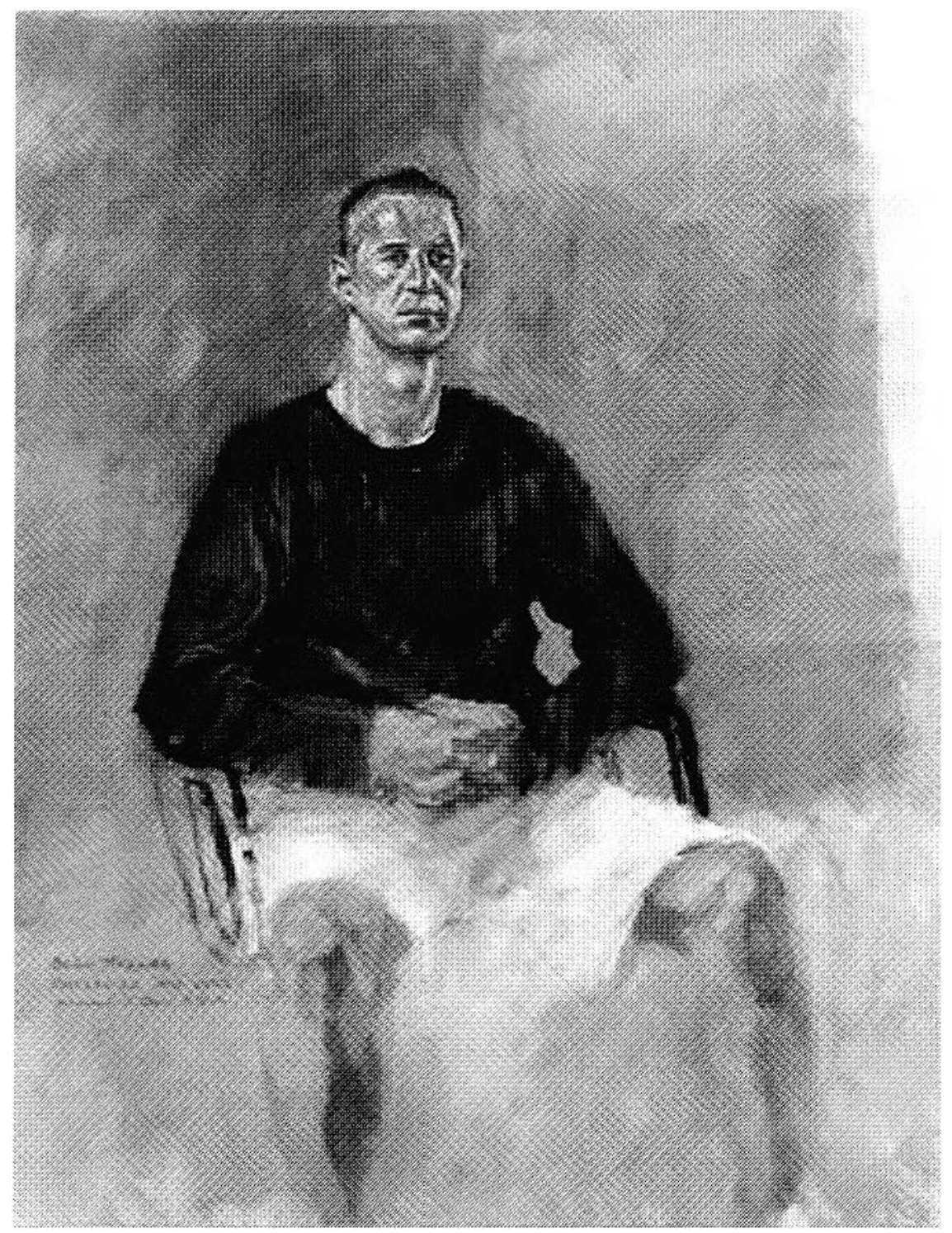

integrity regardless." ${ }^{37}$ Nevertheless, O'Dea later withdrew the work from public sale without any further comment. O'Dea had studied and taught in the United States and was an experienced portraitist. None of his earlier work had engaged the provocative strategies of Harvey or Ofili. While participating in art and education programs in various prisons and rehabilitation centres in Ireland, he had taught at Portlaoise, where Meehan was detained. The portrait was painted at that time, together with additional works for which other prisoners posed. ${ }^{38} \mathrm{Nev}$ ertheless, the choice of subject matter was not merely artistic, it enfolded a text that touched raw nerves with some viewers.

Unlike the portraits of Hindley and Meehan, state portraiture features political motives co-existing with ritual elements. In North Korea, for example, families reportedly installed the leader's portrait in their homes as a mark of profound respect. According to the country's official Central News Agency, the reverence for these images was so great that "many victims of [a recent] rail disaster ... died while trying to save portraits of the 'Great Leader.'" Allegedly these individuals "evacuated" their leaders' portraits to places of safery before searching for members of their own families. ${ }^{39}$ As one Western website noted: "I don't know what is scarier the possibility that [this] might have happened as reported - or - [that] the North Korean government feels ... this is a good way for their people to be seen by the world." 40

Royal portrait rescues were also a feature of the Victorian era in Canada, when

Dublin-based artist Mick O'Dea was described by the art journal Circa as having "done" a "mini-Sensation," with his submission of an acrylic portrait of Brian Meehan to the 173rd annual exhibition of the Royal Hibernian Academy (fig. 6). Again, the sitter was a convicted murderer, serving a life sentence at Portlaoise prison for driving a motorcycle from which six shots were fired to kill investigative reporter Veronica Guerin. Her assassination on 26 June 1996 had been ordered to silence her determined exposure of Dublin's criminal underworld. As soon as the Meehan portrait appeared in exhibition, the Irish Independent reported that Guerin's brother James objected, on the grounds that the work was "offensive and hurtful" to the family. ${ }^{36}$ The artist countered that "a piece of art has its own respect for Imperial institutions was at its zenith, and painted portraits were unique and expensive objects, not easily replaced. ${ }^{41}$ Today, however, such portraits are symbols, not fetishes or even actual "presences." By contrast, state portraits in North Korea still signify "presence." When the western media took up a report from Russia's Itar-Tass news agency that images of Kim Jong Il were disappearing from public sites in Pyongyang, the story was strenuously denied by the Kim government. Western observers cryptically opined that this was "not a meaningless event," while the North Koreans elliptically confirmed that view by calling the reports lies intended to overthrow the regime. At the time, President Kim was at odds with the American government over the future development of nuclear arms, 
so the story carried important implications. Later rumours suggested that the North Korean leader himself might have ordered the removal of the portraits to test the loyalty of those around him. Either way, the removal of, or damage to, Kim's state portraits was read, both in the West and in Asia, as an attempt to impair the power of the leader. ${ }^{42}$

The idea that images possess power in and of themselves has been addressed by others in a number of ways. For example, in the 2004 catalogue of a Hayward Gallery exhibition entitled About Face, curator William Ewing linked the power of the portrait image to anthropological reports of isolated societies in which figural representation was previously little known. Ewing cited the work of anthropologist Edward Carpenter concerning human responses to mirrors and photographic images: "The notion that man possesses, in addition to his physical self, a symbolic self, is widespread, perhaps universal. [A mirror] reveals the symbolic self outside the physical self ... Man's initial response to this is probably always traumatic." ${ }^{33}$ In other cases portraits have been thought to grant any possessor power over the individual portrayed, a corollary perhaps of the Gramscian argument that state oppression can be facilitated through the manipulation of authoritarian public symbols.

The link between art and ritual has also been explored by Columbia University art historian David Freedberg in his 1986 book, The Power of Images. Freedberg looked to sacred objects as a point of entry into this issue. He discussed the legitimation of religious icons and their justification by early Christian Church fathers on the grounds that "the honor paid to an image [passed] to its [heavenly] prototype." 44 This "fusion" of image and Spirit located the divine essence within the earthly object, like a human soul within a corporeal body. The imminence of the divinity, therefore, imbued the Christian icon with legitimacy. ${ }^{45}$ In linguistic terms Freedberg described this as a metaphorical/ metonymic strategy, wherein "all perception elides representation with reality." 46

Freedberg also explored the ritual aspects of secular images, through the medium of effigy. A historical bridge between physical presence and image, the effigy was once used to simulate the presence of absconded criminals. Execution in effigy began in Roman times, coming to the fore in the sixteenth century. In some cases state authorities even used wax effigies stuffed with animal entrails to achieve a more lifelike effect. Such an effigy functioned either as a "habited image" to punish the absent criminal or as a fetishized prop to a didactic piece of staging intended to chasten the audience. ${ }^{47}$ In modern parlance, however, effigies are merely ritual fragments in public demonstrations. Like funerary effigies, they need not resemble the individual whom they purport to represent as long as that person's identity is understood through labelling or other symbolism.
Apart from state-authorized "execution" of effigies, there are also examples of state authorized destructions of official portraits, as when - during the Roman Empire - portraits of a former emperor might be taken down or mutilated (damnatio memoriae). These officially sanctioned removals condemned the previous rulership and marked a new trajectory in state leadership. The incoming ruler was also in a position to select those conventions of portrayal, which, as rhetorical devices, articulated his role most effectively to the public: a practice that assumes encoded and conventionalized communication with the viewer.

In a 1993 study entitled Faces of Power, Andrew Stewart examined the portraits of Alexander the Great, adopting contemporary critical strategies to analyse the place of convention in state portraiture. Stewart noted the nineteenth-century American semiotician Charles Saunders Peirce's differentiations between the "iconic" (that which resembles what it represents), the "indexical" (those elements that call attention to the sitter's personality), and the "symbolic" (signifying the sitter's status in society or in the larger matrix of history). The most significant inscription in Stewart's historiography, however, was his acceptance of Umberto Eco's proposition that the communication of meaning is predicated upon a system of signification that renders all portraits culturally encoded objects, with past and future iconic codes operating in the semantic space between the image, its "pre-encoded subject," and the spectator. Instead of likeness, Stewart suggested, the study of portraits involved the analysis of discourse, the construction and reconstruction of audiences, and the anticipation of future critiques. ${ }^{48}$

While this interpretation casts a wide net, Eco has gone further to suggest that there may be aspects of a text that are subversive or unexpected and, therefore, outside the ambit of cultural encoding: "When these extra-textual [Freudian] 'drives' are not displayed by the text as an activity of ecriture, then I cannot see a way to assume them into a semiotic framework." 49 Is it possible that wartime pillage and iconoclasm reflect preencoded cultural responses? Does vandalism that is both spontaneous and personal exist outside ecriture? As for provocations deliberately introduced by the artist, where violent reaction is an anticipated outcome, are such works fundamentally different from negative audience receptions, where there is no corresponding trigger on the part of the artist?

The fact that figural images are both culturally encoded and intensely charged with issues of power, presence, and referentiality helps to explain why in the Islamic world, as recent protests have made very clear, figural representation for religious purposes is utterly forbidden. Buddhism, on the other hand, has demonstrated a changing tolerance for religious imagery over the centuries. During the 6 th and 5 th centuries $\mathrm{BCE}$, the Gautama Buddha rejected idolatry, but after an an- 
iconic phase of five hundred years Buddhists began creating immense sculptures, initially in India, then along the Silk Road linking India and China. The Buddhas of Bamiyan were carved into the sandstone cliffs of central Afghanistan (ancient Bakhtria) between 507 and $551 \mathrm{AD}$, and a century later the site was surrounded by ten Buddhist monasteries. ${ }^{50}$ When Islamic rule came to Bamiyan, Buddhist religious activity declined, but the images remained largely intact until March 2001, when a decree judged them to be "offensive to Islam." 51 After twenty days of dynamite and tank rounds, the government announced that the Buddhas had been destroyed. ${ }^{52}$ Informed Western commentators such as archaeologist William L. Rathje and art historian Finbarr Barry Flood claimed that the fate of the Bamiyan Buddhas had more to do with politics than religious iconoclasm. Flood attributed the events "not to a timeless theology of images," but to the pressure of contemporary international frictions. For his part Rathje acknowledged the historical antipathy towards human figural imagery in Islam, but emphasized Bamiyan's resistance to the Taliban government as a more important factor..$^{53}$ In any case, however, the vigorous determination with which the Taliban government approached its task met with worldwide protests that were based not so much on religious grounds as on arguments about cultural and heritage. Thereafter, the remains of the Bamiyan site were added to UNESCO's list of World Heritage in Danger, and international funding secured to restore the area and establish a museum, on the grounds that the site had cultural significance to world heritage. ${ }^{54}$

The trajectory of Buddhas from venerated images to remnants, then to iconoclasm and finally to cultural treasures underlines the historicity of cultural responses to images and the complexity of the issues bearing upon interpretation. While art historians have tended to evaluate imagery in relation to its historical context or artistic intention, the shifting values attached to images over time presented more of a problem, at least until art history began to borrow from contemporary literary theory. The impact of the so-called literary turn was summarized in 1991 by Norman Bryson, who repudiated the perceptualist/humanist approach to canonical art history on the grounds that "it leads to a picture of art in isolation from the rest of sociery's concerns." He also rejected Marxist-based social history, because, in his view, art was not simply an "expression in the superstructure of real, determinant events occurring in the economic base." Instead, he proposed that linguistic theory, notably semiotics, offered a fresh alternative for art historians, because signs were consensually based and the analysis of them did not involve guesses about the artist's state of mind. ${ }^{55}$ In these terms, images were embedded within the social from the outset and participated in changing societal frameworks thereafter. For portraiture likeness, factors such as presentation, biog- raphy (of the sitter or of the artist), or even the interaction between the artist and sitter were part of a range of social, political, ideological, or economic contexts to be considered.

As different strategies for interpretation came under scrutiny, post-structuralism emphasized a new direction, which in the words of University of Toronto Professor Emeritus Paul Bouissac was more concerned with "subjective and dialogical dimensions of speech and the social and historical processes of meaning-making than with the description of a-temporal systems of logical difference. Contingent meaning had been explored, as early as the 1920s, in the work of Mikhail Bakhtin and his circle. Bakhtin wrote of dialogism between speaker and listener and between speaker and referential object, through which meaning was negotiated. For him, linguistics and sociology were "co-dependent," and meanings were fluid according to "the socio-ideological and temporal consciousness that framed the particular utterance." Images (and indeed portraits) could be understood in the same way: as cultural products embedded in human ritual, with meaning patinated through the impress of makers, spectators, and participants. ${ }^{56}$ In the 1970s and 1980 s the focus upon the negotiability of meaning was studied by those concerned with reception aesthetics and reader-response theory, notably Hans Robert Jauss and Wolfgang Iser. ${ }^{57}$ Other avenues of exploration were proposed by Roland Barthes, who began by examining bourgeois stereotypes and in 1980 published Camera Lucida. Barthes hypothesized the portraitphotograph as a "closed field of forces," in which self-perception, self-representation, reception, and characterization all occurred simultaneously, encoding the sitter within a presentiment of his/her own future death. Photographic portraits, in Barthes's view, also embodied a paradox between two co-existent messages, one the mechanically produced photographic analogue (a sign without a code), the other the art or trearment of the subject (a sign existing within an extensive network of codes)..$^{58}$

Barthes was among the scholars of the French school, including psychoanalyst Jacques Lacan and structural anthropologist Claude Levi-Strauss, who, beginning in the 1950s, had hypothesized the "empry" or "floating" signifier, to which no signified (nor referent) attached. Derrida took this one step further with the "free play" of signifiers, through which meaning was perpetually deferred by endless semiosis. For Derrida there was no transcendent signified and no immediately identifiable area of certainty, the only avenue for understanding being the marginal aporia that contradicted the ruling paradigms of the text. His work focused scholarship around the collapse of referentiality, a development that conceptually severed the portrait from its traditional references to the sitter.

At about the same time, sociologist Jean Baudrillard suggested an even more radical departure, claiming that contempo- 
rary imagery had entered the realm of the hyper-real. The endless reproduction of images in the media and in advertising effectively emptied them of meaning. His seminal essay of 1970, "Fetishism and Ideology," linked semiotics with materialism to suggest that "contemporary consumer society increasingly [revealed] - through the technological forms of its own self-spectacle - the degree to which commodities [were] no longer objects ... but rather image signifiers." ${ }^{99}$ This vacuity informed the economic sphere, but Baudrillard also perceived the visible machinery of icons to be substituted for the Idea of God, thereby rendering the system of belief weightless (and meaningless). Baudrillard's ideas effectively revisited the fears of the iconoclasts, who, centuries before, had objected that sacred images might impede communion with the Godhead. ${ }^{60}$ The simulacrum, particularly its explanation of commodity images and mass culture, displaced the idea of representation as an effective strategy for figural interpretation.

The concept of the self-sufficient object has also figured in writings on fetishism in the 1990s. Michael Taussig devised the term state fetishism to describe "the mystical foundations of State authority," which were implicated with "the peculiar sacred and erotic attraction, even thralldom [sic], combined with disgust, which the State holds for its subjects." Taussig equated the abstract entity known as the state with Durkheim's view of the fetish object, which both embodied and erased the traces of the society from which its power derived:

\begin{abstract}
What we are inching toward here is a critical dismantling of the sign in which the image lifts off from what it is meant to represent. In this peeling off of the signifier from its signified the representation acquires not just the power of the represented but power over it as well. What is fascinating here is that what we might call (with some perplexity) the image itself should be granted such a power - not the signified, the sacred object, the totemic species, animal, vegetable, and so forth, but the signifier itself prized apart from its signification so as to create a quite different architecturc of the sign in which the signified is erased. ${ }^{61}$
\end{abstract}

The fetish alone, without external reference, might thereby assume a self-sufficient power, apart from the circumstances of its making, while at the same time being able to affect events in the present and having an ambiguous role in future praxis.

The problem of the referential ritual image, the floating signifier and the fetish object still haunts the interpretation of portraiture. Wendy Steiner attempted to reconcile the dilemma in the following terms:

The painted portrait is assumed to be iconic, resembling what it represents. It is also indexical, however, gesturing

\begin{abstract}
towards the extra-artistic actuality of the subject and functioning in an almost magical fashion so as to render that subject present. But in doing so, it depends on semiotic symbols - title, iconography - to establish the subject's identity in a definitive manner. A fusion of icon, index, and symbol, of centripetal and centrifugal reference, the portrait is an extremely complex semiotic structure. ${ }^{62}$
\end{abstract}

Steiner then addressed the serial imagery of the 1960s silkscreen portraits by Andy Warhol. These were based on well-known photographs of political figures and Hollywood stars, repetitively reproduced by the artist as multi-coloured silkscreen images, which thereafter assumed an autonomous aesthetic character completely divorced from the historical context of the original photograph. This type of repetition could make no claim to uniqueness, but Steiner found convincing Warhol's explanation that "repetition adds up to reputation." 6.3

Shearer West's 2004 publication, Portraiture, takes an entirely different approach:

A portrait has qualities of all three [Peirccan signs]: it resembles the object of representation (icon), it refers to the act of sitting (index), and it contains gestures, expressions, and props that can be read with knowledge of social and cultural conventions (symbols)..$^{64}$

As for Warhol, West referred to Walter Benjamin's "Work of Art in the Age of Mechanical Reproduction" and Baudrillard's critique of the simulacrum, to deconstruct Warhol's portraits of Hollywood "royalty." Because of their ubiquity, West, like Benjamin, saw popular celebrity photographs as lacking any presence or "aura," while at the same time facilitating some kind of synthetic intimacy, upon which fans (and stalkers) thrive. Developing and marketing the public image of a star, in West's view, involved a culturally determined interface with society's perceptions of beauty and deportment, both of which are linked to commodity fetishism. The sense of high camp in Warhol's image-making, West argued, equated the commodification of celebrity with that of a soup label or a Brillo box.

Sociologist and filmmaker Edgar Morin has suggested of celebrity that "we project any number of needs and desires that cannot be fulfilled in real life into the exalted, mythical being [of the star]." ${ }^{15}$ Hence, the image of the star may have less to do with individual celebrity than the liberation of the audience's fantasies. The recent video portrait of a sleeping David Beckham, by Sam Taylor-Wood, is a case in point. When the work was exhibited at the National Portrait Gallery in London, it offered the quintessential simulation of intimacy for the fan/voyeur. It fetishized the celebrity image to the extent of endowing the recorded presence with a self-sufficiency that carried it beyond 
the simulacrum. At the same time the artist and the celebrity subject so rigidly control access to any record of the work's display that the "portrait" has all but disappeared from public view. ${ }^{66}$

Eco's concern for the intra- and extra-textual, and for culturally determined conventions that may govern the type of image produced, also addresses the changing reception of those conventions over the life of the image. Art and particularly portraits hold the potential for many different "translations," from veneration to vandalism, and for many historiographic narrations, all of which arc handled differently in the hands of different audiences. As Naomi Cummings observed with reference to musical performance:

A fclt opposition berween the musical sensuality that is sanctioned in certain styles, and a socialization to restraint [is] an indicator of a cultural conflict between two different methods of valuing ... These questions / of tension between personal expression and formal modes of understanding] required a specific kind of philosophy in order to be addressed [to] take account of the practical experience of being a musician. ${ }^{67}$

Cummings knew that music was not simply convention and the expectations that attach to the work of art over time. New interpretations and responses may occur in response to preexisting conditions at any time. Indeed, they may transcend the existing frame altogether. Hence, the strategies with which the aesthetic object is addressed must be as fulsome as the possibilities presented.

\section{Notes}

1 Associated Press, "Giant Saddam busts dismantled," The Sydney Morning Herald, 3 Deccmber 2003, http://www.smh.com.au (accessed 30 December 2004).

2 Hannah Bloch, Bcn Wedeman, and the Associated Press, "Photos document destruction of Afghan Buddhas," CNN.com/World, 12 March 2001, http://www.edition.cnn.com/2001/.../asiapcf/central/ 03/12/afghan.buddha.02 (accessed 13 May 2005).

3 Dario Gamboni, The Destruction of Art: Icononclasm and Vandalism since the French Revolution (New Haven, 1997), includes a historiography of vandalism, in which an approach proposed in a 1984 study by social scientist I.uc Boltanski is endorscd. Boltanski saw vandalism as part of a continuum, be it individual or collective acts that are normative or transgrcssive. However, Gamboni also refers to the classificatory approach of David Freedbcrg, The Power of Images: Studies in the History and Theory of Response (Chicago and London, 1989), concerning attention-secking acts, attempts to deprive an imagc of its power, and acts that undermine an individual by damaging a symbol of his/her power.

4 Gamboni, The Destruction of Art, 18-19.
5 Margaret Iverson, "Readymadc, Found Object, Photograph," Art Journal 63 (Summer 2004), 44-57, has explored the parallels berween Lacan's concept of Tuche and Barthes's punctum, described by Lacan scholar Malcolm Bowie as the "ghost of referentiality." Sec also Jacques Lacan, The Four Fundamental Concepts of Psychoanalysis, ed. Jacqucs-Alain Miller, trans. Alan Sheridan (New York, 1998), 92; Roland Barthes, Camera Lucida: Reflections on Photography (London, 1980). A convenient summary of Lacanian issues is offered by Dino Felluga, "Terms Used by Psychoanalysis," Introductory Guide to Critical Theory, http://www.cla.purdue.edu/ acadcmic/engl/theory/psychoanalysis (accessed 2 March 2006).

6 Umbcrto Eco, A Theory of Semiotics (Bloomington, 1979), 27576.

7 W.I.. Rathje of Discover Archaeology, "Why the Taliban are Destroying Buddhas," USA Today, 22 March 2001, http:// www.usatoday.com/new ...rchaeology/2001-03-22-afghanbuddhas.hem (accessed 13 May 2005). For methodological approach to this issue, see Hans-Georg Gadamer, Truth and Method, trans. Garret Barden and William Doerpel (New York, 1975).

8 Richard Brilliant, Portraiture (London, 1991), 7-21, discusses many approaches to the portrait genre as does Shearer West, Portraiture (Oxford, 2004), 9-41.

9 Wendy Kaminer, Free for All: Defending Liberty in America Today (Boston, 2002), 60-63, offers one populist critique of flag idolatry.

10 Arnold Goldstein, The Psychology of Vandalism (New York, 1996), 32.

11 By "portraval" I mean interpretation, whereas "portrayed" can have a range of mcanings, from likeness or representation that substitutes for absence to so-callcd residual referentiality or ghostly presence.

12 "Iraq: One Year later," Ottawa Citizen, 20 March 2004, B4; Tony Karon, "Baghdad Falls: Regime change becomes reality in Saddam's capital, but the war isn't over yet," Time, 9 April 2003, n.p.

13 Chris Cobb, "Opcration Network Storm: The War Against Iraq as brought to you by $\mathrm{ABC}, \mathrm{NBC}, \mathrm{CNN}$ and the rest," Ottawa Citizen, 19 October 2003, C9, with information quoted from Shcldon Rampton and John Stauber, Weapons of Mass Deception (Harmondsworth, 2003).

14 Gamboni, The Destruction of Art, 163, n. 89, cites Benjamin Buchloh concerning the Tilted Arc controvcrsy. Sce also Jon Elmer, "Army report confirms Psy-ops staged Saddam statue toppling," 7 he NewStandard, 3 July 2004, http://newstandardnews.net/content (accessed II May 2004).

15 Stanley Cohen, "Property Destruction: Motives and Meanings," ed. Colin Ward, Vandalism (London, 1973), 42-53, names five different categories of vandalism - acquisitivc, tactical, vindictive, playful, and wanton or malicious. See also Catherinc DonaldsonEvans, "Saddam Statues, Souvenirs Await Their Fate," Fox News, 14 April 2003, http://www.foxnews.com (accesscd 30 December 2004).

16 Karina Roman, "Statue of Saddam a bust for museum," Ottawa Citizen, 29 March 2004, A 14; Anita Ramasastry, "Toppling Saddam, Not His Statues," FindLaw's Writ, 22 April 2003, http:// writ.news.findlaw.com (accessed 30 December 2004). 
17 Janis Kent Cakars, "They All Fall Down: Toppling Vladimir Josef Felix Nicolae Honecker Hussein," Nonviolent Activist: The Magazine of the War Resisters League, July-August 2003, http:// www.warresisters.org (accessed 30 December 2004).

18 Gamboni, The Destruction of Art, 52-57.

19 Cakars, "They All Fall Down," 3; Doug Bandow, "Building a New Nation - and Dealing with the Past," National Review Online, 24 September 20()2, http://www.cato.org/dailys/09-30-02.html (accessed 28 May 2005); Nick Allen, "Stalin's quiet 'rehabilitation," Ottawa Citizen, 21 April 2005, A14.

20 "Historic Figures: Josef Stalin," BBC History Homepage, http:// www.bbc.co.uk/history/historic-figures/stalin-josef.shem (accessed 31 March 2006).

21 Allen, "Stalin's quiet 'rehabilitation," A14.

22 "Stalin World," City Paper: The Baltic States, http://www. balticsww.com/stalin_world.htm (accessed 16 January 2005).

23 June Ardiel, Sculpture/Toronto: An Illustrated Guide to Toronto Historic and Contemporary Sculpture with Area Maps, photographs by Alec Capon and Ken Borden (Toronto, 1994), 71; Gamboni, The Destruction of Art, 317, plate 144.

24 "Mayor Dedicates Statue," Globe and Mail (Toronto), 26 May 1969, 11.

25 Gamboni, The Destruction of Art, 51.

26 Ernst van Alphen, "The Portrait's Dispersal: Concepts of Representation and Subjectivity in Contemporary Portraiture," Portraiture Facing the Subject, ed. Joanna Woodall (Manchester, 1997), 240 , states, "authority is not so much the object of its portrayal but its effect." Refcrence courtesy of Andrew Kear, "Governing Likenesses: The Production History of the Official Portraits of Canadian Prime Ministers, 1889-2002," M.A. thesis, Carleton University, 2004.

27 Antonio Gramsci, Selections from Cultural Writings (Cambridge, MA, 1985), 389.

28 Michael Dartnell, "Political Murals in Belfast," /wallsland/placesl, http://zeus.uwindsor.ca/courses/ps/dartnell/wallsandplaces.html (accessed 21 June 2005); Neil Jarman, ed., "On the Edge: Communicy perspectives on the civil disturbances in North Belfast, June-September 1996," CAIN: Jarman, Neil (ed.) (1996) On the Edge, http://cain.ulst.ac.uk/cdc/edge/jarman96.htm (accessed 21 September 2005).

29 Dartnell, "Political Murals."

30 Bill Rolston, Drawing Support: Murals in the North of Ireland (Belfast, 1992), and Politics and Painting: Murals and Conflict in Northern Ireland (London, 1991).

31 Peter Burke, The Fabrication of Louis XIV (New Haven, 1992); Partha Chattcrjee, "The sacred circulation of national images," Traces of India: photography, architecture and the politics of representation, 1850-1900 (New Haven, 2003), 276-91.

32 Caroline Davies, "Gadzooks! Prince Philip is not amused by the portrait with 'a great schonk' and a bluebottle on his shoulder," Daily Telegraph, 30 April 2004, 3. See also the furor over Mark Quinn's sculpture of Alison Lapper, pregnant, Kevin Ward, "'Wrong place, wrong statue' critics say," Ottawa Citizen, 18 March 2004, Al6; "London needs more contemporary pieces to make it more
21 st Century," Fourth Plinth, http://www.fourthplinth.co.uk/ marc_quinn.htm (accessed 4 January 2005); and "Art on the 4th plinth-Marc Quinn," BBC-London-Your London-4th Plinth, http:/ /www.bbc.co.uk/yourlondon/fourth_plinth/marc_quinn.sheml (accessed 04 January 2005).

33 Jonathon Jones, "Graham Sutherland's Winston Churchill (1954)," Guardian, 3 November 2001, Graham Sutherland - The Churchill Portrait. http://www.geocitics.com/pantherprousa/sutherland (accessed 10 February 2006).

34 "Artists: Marcus Harvey," WhiteCube, http://www.whitecube.com (accessed 19 April 2005); Heather Mallick, "Myra Hindley, 1942 2002: The Face of Evil," Globe and Mail (Toronto) 23 November 2002, F7.

35 "The Holy Virgin Mary," Art Crime, http://www.renewal.org.au/ artcrime/pages/c_ofili.html (accessed 15 April 2005); John Haber, "The Shock of the Not So New," Haber's Art Reviews: The Art World after 'Sensation,' http://www.haberarts.com/neoneo.htm (accessed 4 October 2005).

36 "Family outraged as portrait of Guerin killer is exhibited," Irish Independent, 27 May 2003.

37 "Facing art: an audience with Mick O'Dca," Circa, 28 June 2004, http://www.recirca.com/artncws/308.shtml (accessed 19 April 2005).

38 Mick O'Dca biography, Arts Council, http://www.artscouncil.ie/ aosdana/biogs/visualarts/michaelodea.heml (accessed 19 April 2005).

39 Richard Spencer, "Train victims died saving portraits of the 'Great Leader," Telegraph (London), 29 April 2004, 17.

40 Posted by John Rogers, 4 May 2004, All AgitProp, all the Time, hetp://fim.ondragonswing.com/archives (accessed 30 December 2004).

41 "Montreal Walking Tours," Vehicule Press: Guide to Montreal, http:// www.vehiculepress.com (accessed 19 April 2005), reports that the items saved from the Montreal parliament fire, 25 April 1849, included the legislative mace and a portrait of Queen Victoria, which now hangs outside the Senate Chamber in Ottawa.

42 "Public portraits of North Korea's Kim disappear," Daily Tïmes (Pakistan), 17 November 2004, http://www.dailytimes.com.pk (accessed 15 April 2005); Association for Asia Rescarch, "Removal of Kim Jong Il Portraits in North Korea Causes Speculation," VOA News, 13 November 2004, http://www.asianresearch.org/2419.html (accessed 15 April 2005); Kosuke Takahashi, "Korea: The case of Kim Jong-il's missing portraits," Asia Tïmes, 20 November 2004, http://www.atimes.com/atimes/Korea (accessed 15 April 2005); Gamboni, The Destruction of Art, 195, quotes Freedberg, Power of Images, 25-27, 35.

43 William A. Ewing, "The Faces in the Mirror," in About Face: Photography and the Death of the Portrait, exh. cat., London, Hayward Gallery (London, 2004), 9, 10; Freedberg, The Power of Images, 279. For concerns about portrait inscription among the First Nations described by Euro-Canadian artist Paul Kane during an 1846 to 1848 trip to the pre-Confederation Canadian west, see J. Russell Harper, Paul Kane's Frontier (Ottawa, 1971), 58, 101, 116, 119: “[A chief named Mani-tow-wah-bay, or 'He-Devil'] 
anxiously inquired what I wanted the likenesses for. In order to induce him to sit, [Kane] told him that the [likenesses] were going home to his great mother, the Queen. He said that he ... was very desirous of seeing her ... It pleased him much, that his second self would have an opportunity of seeing [the Queen]."

See also Emily Carr, Klee Wyck, in The Emily Carr Omnibus, introduction by Doris Shadbolt (Vancouver, 1993), 25-26, for a similar response decades later among the Chinook of the Northwest coast: "One day, by grin and gesture, I got permission to sketch an old mat-maker. She nodded and I set to work ... ['Then a man] shoured ... and the old woman's smile dricd out. 'Klatawa' (Chinook for 'Go') she shoured, and I went ...

[Later] Mrs. Wynook told how the old Indians thought that the spirit of a person got caught in the picture of him, trapped there so that, after the person died, it had to stay in the picture ... 'Tell her that I will not make any more pictures of the old pcoplc,' I said."

44 Freedberg, Power of Images, 29-32; "The Seven Ecumenical Councils of the Undivided Church," Nicene and Post-Nicene Fathers, 2nd series, eds P. Schaff and H. Wace, trans. H.R. Percival (rcprint Grand Rapids, MI, 1955) 14: 549-51.

45 Rupert Shepherd, "Art and Life in Renaissance Italy: A Blurring of Identities?" Fashioning Identities in Renaissance Art, ed. Mary Rogers (Aldershot, 2000), 63-77; Freedberg, Power of Images, 203. Another book by Rupert Shepherd entitled Presence in Images: The Inherence within Images and Other Objects is to be rcleased shortly.

46 Freedberg, Power of Images, 30, 393, n. 26, quotes St Basil, De spirito sancto.

47 Freedberg, Power of Images, 259-62.

48 Andrew Stewart, Faces of Power: Alexander's Image and Hellenistic Politics (California, 1993), 66-69.

49 Umberto Eco, A Theory of Semiotics, (Bloomington, 1976), 318.

50 Sally Hovey Wiggins, Xuanzang: A Buddhist Pilgrim on the Silk Road (Boulder, 1998); Richard Foltz, Religions of the Silk Road (New York, 1999).

51 Bloch and Wedeman for AP, "Phoros document destruction of Afghan Buddhas."

52 BBC News, "Reporters see wrecked Buddhas," 26 March 2001, BBC News SOUTH ASIA, http://news.bbc.co.uk (acccssed 13 May 2005).

53 Rathje, "Why the Taliban are destroying Buddhas"; Finbarr Barry Flood, "Berween Cult and Culture: Bamiyan, Islamic Iconoclasm, and the Museum," Art Bulletin 84 (December 2002), 641-59.

54 UNESCO, Convention Concerning the Protection of World Cultural and Natural Heritage (Suzhou, 2004), 66, regarding 28 COM 15A.22; UNESCO, Convention Concerning the Protection of the World Cultural and Natural Heritage (Durban, 20(05); "Cultural Landscape and Archaeological Remains of the Bamiyan Valley,
Afghanistan," UNESCO World Heritage: Cultural Landscape and Archaeological Remains, http://whc.unesco.org (accessed 10 August 2005).

55 Naomi Cumming, The Sonic Self: Musical Subjectivity and Signification (Bloomington and Indianapolis, 2000), 16-17.

56 Paul Bouissac, "Saussure's Legacy in Semiorics," Cambridge Companion to Saussure, ed. Carol Saunders (Cambridge, 2004), 240260.

57 Hans Robert Jauss, "Art History and Pragmatic History," Toward an Aesthetic Reception (Minneapolis, 1982), 46-75; Wolfgang Iser, The Range of Interpretation (New York, 2000), 5.

58 Roland Barthes, Camera Lucida: Reflections on Photography, trans. Richard Howard (New York, 1981), 13-14; Roland Barthes, "Myth Today," Mythologies, selected and trans. Annctte Lavers (New York, 1957), 109-59; Roland Barthes, "The Photographic Message," Image, Music, Text, essays selected and trans. Stephen Heath (New York, 1977), 15-31; Roland Barthes, "The Rhetoric of the Image," Classic Essays on Photography, ed. Alan Trachtenberg, (New Haven, 1980), 287-90.

59 William Pietz, "Fetishism and Materialism: The Limits of Theory in Marx," Fetishism as Cultural Discourse, eds Fmily Apter and William Pietz (Ithaca and London, 1993), 119-1551.

60 Jean Baudrillard, Simulacra and Simulation, trans. Sheila Faria Fraser (Ann Arbor, 1997), 1-7; Gilles Deleuze, "Plato and the Simulacrum," trans. Rosalind Krauss, October 27 (Winter 1983), 45-56.

61 Michael Taussig, "Maleficium: State Fetishism," in Apter and Pietz, Fetishism as Cultural Discourse, 217-47.

62 Wendy Steiner, "Postmodernist Portraits," Art Journal 46 (Autumn 1987), 173-77.

63 Steiner, "Postmodernist Portraits," 174; Steven Kurtz, "Uneasy Flirtations: The Critical Reaction to Warhol's Concept of the Celebrity and of Glamour," in Alan R. Pratt, ed. The Critical Response to Andy Warhol (Westport, Connecticut, 1997), 255-57.

64 Shearer West, Portraiture (Oxford, 2004), 41. See also William V. Ganis, "Andy Warhol's Iconophilia," In-Visible Culture (2002), online journal at http://www.rochester.edu/in_visible_culture/issue3/ganis.hrm (accessed 4 January 2005); Hciner Bastian, Andy Warhol Retrospective, ex. cat., Museum of Contemporary Art (Los Angeles, 2001), 294-96; Ian M. Thom, Andy Warhol Images, ex. cat., Vancouver Art Gallery (Vancouver/Toronto, 1995), 12, 13 , $16,33$.

65 Klaus Honef, Andy Warhol (1928-1987): Commerce into Art, trans. Carole Fahy and I. Burns (Cologne, 200()), 8.

66 "We're to blame if an artist gets Beckham in bed," Sunday Times, 2 May 2004, 3G.

67 Cummings, Sonic Self, 16-17. 